\section{当科にて経験した完全型アンドロゲン不応症 例に於ける腹腔鏡による検査・手術について}

兵庫医科大学産科婦人科学教室、

○小森 慎二、堀内 功、田中宏幸、霞 弘之、 辻 芳之、香山 浩二

アンドロゲン不応答症 (androgen insensitivity syndrome: AIS）は、アンドロゲンレセプターの 異常による性分化異常といわれている。本邦でも 数万例に 1 例の頻度に認められている。このAIS 症例においては、精巣が腹腔内か鼠径部に存在す ることがわかっている。そしてこれらの精巣より 腫瘍が発生することが報告されており、AISと診 断されれば、性腺である精巣を摘出することが一 般には必要であると考えられている。今回、これ までに当科にて経験したAIS患者 7 例に対する腹 腔鏡を用いた精巣の検索と摘出についてまとめて 報告する。これらのAIS症例においては、全例腹 腔鏡を実施した。その結果、全例において精巣が、 腹腔内に認められた。初期（平成 2 年まで）に経 験した 3 例では、開腹にて精巣を摘出していたが、 後（平成 6 年以降）の 4 例は腹腔鏡下に精巣を摘 出した。腹腔鏡下手術では精巣導帯及びそこにあ る精巣動静脈を的確に結紮切断することができれ ば摘出は容易であった。しかし、精巣の存在する 部位により、周囲の血管との関係及び尿管との関 係を十分に検討したうえで慎重に処理することに 留意すべきである。今回、当科にて経験し腹腔鏡 にて摘出した症例を中心に文献的考察も加えて報 告する。

\section{妊娠 12週に施行した腹腔鏡により診断した 1 年 7 カ月の経過を有する虫垂炎の一例}

関東労災病院産婦人科

○袖本武男、関博之

虫垂炎は急性腹症の中で頻度の高い疾患であ り、婦人科的な原因による骨盤腹膜炎との鑑別は 日常臨床においてしばしば問題となる。しかしそ の診断は決して容易ではなく、手術適応の判断は 困難な場合もある。今回我々は初診時より 1 年 7 カ月後の妊娠12週時に施行した腹腔鏡によって診 断し得た虫垂炎の症例を経験したので報告する。 症例は30歳、1 回経妊 1 回経産。右下腹部痛を主 訴に平成 年 7 月日当院外科受診。虫垂炎を疑 われるも確定診断に至らず抗生物質投与により症 状軽快したため 5 日間で退院となった。年 6 月 にも同様の症状が出現したが、近医の外科・当院 外科いずれでも虫垂炎は否定的ということで、当 科入院の上骨盤腹膜炎として抗生物質による治療 を行った。治療により症状軽快し退院となった。 9 月に再度下腹部痛出現したため、精查目的の腹 腔鏡を勧めたが本人の同意が得られなかった。そ の後11月を最終月経として妊娠。年 1 月回当 科受診し、妊娠 8 週と診断された。ロ月⿴日（12 週 0 日）下腹部痛のため当科救急受診。腹部全体 に圧痛を認め、血液検査では $17500 / \mathrm{mm} 3$ 、 $\mathrm{CPP} 2.45 \mathrm{mg} / \mathrm{dl}$ と炎症所見を認めた。抗生物質投 与により保存的治療を行う方針としたが、その後 腹痛の症状が強くなったため診断的腹腔鏡を施行 した。子宮・付属器に異常所見を認めず、腫大し 膿苔の付着した虫垂を認めた。虫垂の腫大と虫垂 間膜の肥厚が著明であるため、虫垂切除は直視下 に行う方針とした。腹腔鏡下に虫垂と周囲との瘉 着剥離を行った後に、右下腹部のトロッカー挿入 部の創を延長して虫垂を体外に引き出した上で切 除した。腹腔内にドレーンを留置し手術を終了と した。術後経過は良好で術後9日目に退院となっ た。その後の妊娠経過には異常を認めていない。

本症例のように虫垂炎はその診断が困難である 場合も多く、腹腔鏡は診断的有用性が高いと考え られた。 


\section{腹腔鏡下手術後のADL回復についてのアンケ 一下解析}

順天堂大学

○島貫洋人、熊切 順、菊地 盤、北出真理、 武内裕之、木下勝之

【目的】腹腔鏡下手術は一般的に低侵襲であり、 術後のADLの回復や変化については経験的に早 いであろうと考えられるが、実際に調查した報告 はない。そこで退院時にアンケートを配布し、術 後 1 ケ月までの回復状況について調查・解析し た。【方法】2003年10月．2004年 3 月までに施行 した腹腔鏡下手術334例のうち、子宮全摘術と緊 急手術および術後長期入院症例を除く296例を対 象とし、退院時に『退院後から創痛がなければ何 をしてもかまわない、ただし第 6.7 病日の術創 部チェックまで入浴とスポーツは避ける』ことを 全例に指導し、アンケートを配布した。退院は第 2 病日を原則としたが、退院を延期した症例は 16 例 $(5.4 \%)$ で最長第 8 病日までであった。アン ケートは日常生活の行動（家事、買い物、自転車 の運転、入浴、事務系就労、軽運動、肉体労働、 スポーツ）がいつから可能であったかを記録して もらい、術後 1 ケ月に外来で回収した。

【成績】アンケートの回収率は65.5\%であった。 それぞれの日常生活の行動が可能になった術後日 数（病日）の中央値は家事 5 日、買い物 5 日、入 浴 9 日、自転車の運転 12 日、事務系就労 11 日、軽 運動12日、肉体労働14.5日、スポーツ18日であっ た。負担が大きいと思われる行動ほど長い傾向で あった。行動の項目うち有効回答が多かった家事、 買い物、事務系就労の 3 項目について術式別また は手術時間、出血量の多寡により比較したが有意 差はなかった。

【結論】腹腔鏡下手術後のADLの回復は早く、ほ とんどの症例において 1 ケ月以内に術前の日常生 活に戻ることが可能であった。また、回復状況は 術式や侵襲の大きさによらず、ほほ一定している ことが明らかになった。しかし日数にはばらつき があり、患者それぞれの痛みの感受性や性格、生 活環境などの因子に影響を受けると思われた。こ の結果をもとに、今後の退院時指導を再評価する 予定である。

\section{当院の腹腔鏡下手術の検討}

公立陶生病院、安城厚生病院

○浅井英和、伊藤順子、林加奈子、片野衣江、 岡田節男、石田昭太郎

近年腹腔鏡下手術は産婦人科手術において大き な位置を占めるようになってきた。腹腔鏡下手術 には疼痛が少ない、美容的であるなどの多くのメ リットがある一方、開腹術にはない特有の合併症 があることも確かである。当院では1995年に腹腔 鏡下手術を導入後、年々件数は増加しており多く の婦人科良性疾患に対して適応となっている。第 一トロッカーの挿入は基本的にオープン法を用 い、気腹法にて腹腔内の視野を得たが、症例や疾 患に応じて適宜吊り上げ法も用いている。1999年 11月より2003年12月までに当院で腹腔鏡下手術を 行ったのは 406例であった。そのうち、最初の 観察時に高度の癒着や大きさなどから腹腔鏡下手 術適応外と判断し開腹移行した症例 24 例を除 いた382例を対象とした。382例中なんらかのトラ ブルを認めたものは18例（4.7\%）であった。手 術中にトラブルを認めたものは11例 $(2.9 \%)$ で、 そのうち開腹術に移行した症例は 8 例 $(2.1 \%)$ であった。開腹せずに対処した症例は 3 例 $(0.78 \%)$ であった。術後に起こった合併症は 8 例 $(2.1 \%)$ で、すべて再手術を要したものであ った。そのうち、開腹した症例が 5 例 $(1.0 \%)$ で腹腔鏡で対処した症例が 3 例 $(0.8 \%)$ であっ た。腹腔鏡下手術での合併症を減らしていくため には、適応や術式の選択を検討し、技術の習得、 トラブル発生時の対処にも習熟していくことが必 要であると考えられた。 


\section{骨盤腹膜炎に対する腹腔鏡下手術 3 症例の経 験}

石川県立中央病院 産婦人科

○石川博士、斎藤里奈、吉成秀夫、藤井亮太、 平吹信弥、佐々木博正、干場 勉、朝本明弘

【緒言】骨盤内に膿瘍を形成した骨盤腹膜炎は保 存的加療だけでは治瘉が困難なことが多く、適切 な時期に手術を行わないと、敗血症やDICなどの 合併症により全身状態が悪化する可能性がある注 意すべき疾患である。今回我々は骨盤内膿瘍を形 成した骨盤腹膜炎に対し腹腔鏡下手術を施行し、 経過が良好だった 3 症例を経験したので報告す る。

【症例 1】47歳、下腹部痛と発熱を主訴に受診。 左卵巣に膿場を形成していて、腹腔鏡下胵式子宮 全摘術 (LAVH)、左附属器摘出術を施行した。 手術時間は 138 分、出血は $30 \mathrm{ml}$ で膿瘍形成の原因 は筋腫分婏に伴う上行性感染と思われた。

【症例 2 】51歳、下腹部痛と発熱があり、他院に て抗生片投与を受けるも改善せず、受診。左卵管 に膿瘍を形成していて、LAVH、両側附属器摘出 術を施行した。手術時間は250分、出血は630ml で膿瘍形成の原因は子宮内避妊器具からの感染と 考えられた。

【症例 3 】77歳、心不全徴候で発症し、原因精查 中に子宮の腫大および異常帯下を認め、受診。子 宮溜膿腫、右卵管膿瘍の診断にて心不全、感染の 改善後にLAVH、両側附属器摘出術を施行した。 手術時間は235分、出血は $430 \mathrm{ml}$ で術後 5 日目に 退院した。症例 $1 、 2$ は術前に高熱と白血球数、 CRP值の異常高値を認めたが、術後は速やかに全 身状態の改善がみられた。

【考察】骨盤内に膿瘍を形成した骨盤腹膜炎に対 する腹腔鏡下手術は、膿瘍の破綻や炎症に伴う他 臓器との瘉着により、手術手技は慎重に行う必要 がある。そのため、非瘉着症例と比較して手術時 間は延長するが、今回の経験から、腹腔鏡下に膿 瘍を摘出し適切にドレナージを行うことは、術後 早期の回復、全身状態の改善につながり、有用な 手技であると考えられた。

\section{Pelvic Congestion Syndromeの腹腔鏡所 見}

大阪市立大学医学部産科婦人科学教室 ${ }^{1}$ 、大阪市立住 吉市民病院産婦人科 ${ }^{2}$

○安井智代、角 俊幸1、平井光三1、本田謙一 ${ }^{1}$ 、 中村哲生 ${ }^{2}$ 、石河 修 $^{1}$

Pelvic Congestion Syndromeとは女性骨盤腔内 の静脈系のうっ滞と骨盤静脈瘤を生じ、下腹部痛 を主とした様々な症状を引き起こす症候群であ る。1858年にAranにより初めて報告され、1900 年代中頃に欧米で疾患概念として確立されたが、 本邦ではあまり認識されていない。性成熟期、特 に多産婦に多く、慢性的な下腹部鈍痛が主症状で、 月経過多、不正性器出血、性交時痛などを伴うこ ともある。診断には、これらの症状を有すること に加えて、MRI - MRA - CT ・血管造影などの画 像所見が補助診断として有用であるとされてき た。今回、われわれは腹腔鏡がその診断に有用で

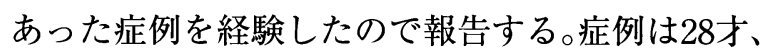
2 経妊 2 経産。 7 年前第 2 子出産後より慢性的な 下腹部痛と月経困難症が出現したため、前医で GnRHa療法を施行された。症状が改善しなかっ たため腹腔鏡を施行したところ、腹腔内に瘉着は なく子宮内膜症r-AFS分類ではStage Iであった。 その他の所見として、左側広間膜下の著明な静脈 怒張が認められた。月経困難症に対しては

LUNA (laparoscopic uterosacral nerve ablation) を施行されたが、術後症状の改善が認められなか ったため当院紹介となった。症状・腹腔鏡所見か らPelvic Congestion Syndromeの可能性が考えら れたため血管造影検查を施行したところ、左腎静 脈の血流は下大静脈への流入障害が強く、左卵巣 静脈を介して骨盤腔内への明らかな逆流が認めら れた。血管造影下に左卵巣静脈塞栓術を施行し左 卵巣静脈への逆流を遮断したところ、慢性的な下 腹部痛は消失しQOLが改善した。原因不明の下 腹部痛を有する症例に対し、腹腔鏡で骨盤内の静 脈系のうっ滞を認めた場合にはPelvic Congestion Syndromeの可能性を考慮するべきで あると考えられた。 


\section{腹腔鏡下手術が有効であったchronic pelvic pain $の 3$ 例}

\author{
熊本大学大学院医学薬学研究部 \\ 先端生命医療科学部門 \\ 成育再建 / 移植医学講座 産科学分野 \\ 総合医薬科学部門生態機能病体学講座婦人科学分野
}

○岩政 仁、角田みか、本田律生、岡村 均

Chronic pelvic painは月経周期と関連が無くか つ 6 ケ月以上持続する痛みを有し、それが日常生 活を障害するために保存的もしくは外科的治療を 必要とするものと定義されている。

今回、異なる病態を示したchronic pelvic pain の 3 例で、いずれも腹腔鏡下手術で症状が改善し た症例を経験したので報告する。

症例 1 は27歳 2 回経妊 1 回経産の症例で 分婏 後より生じた下腹痛および性交痛を訴えていた。 前医のMRIでchocolate cystを疑い偽妊娠療法を 受けていたが、下腹痛の増悪を認め当科に紹介さ れた。手術時ダグラス窩に周囲組織と癒着を伴う クルミ大の遊離性腫瘤を認め、その摘出を行った。 術後腹痛は軽減し、約半年で自然周期の妊娠成立 を認めた。症例 2 は34歳 0 回経妊 0 回経産の症例 で 下腹痛を主訴に来院し、平成14年 6 月昌腹 腔鏡下に子宮内膜症（r-AFS78）の診断で左卵巣 囊腫摘出術、骨盤内瘉着剥離術および子宮筋腫核 出術を施行した。しかし術後にそれまで感じなか った排便時の強い腹痛および腰痛を感じるように なり、平成15年10月日日に当科へ再受診した。子 宮内膜症再燃の疑いで腹腔鏡下手術の適応とし た。右付属器に子宮内膜症は認められたが（rAFS20）、排便時痛の原因は直腸およびS状結 腸が左卵巣および広間膜後葉へ強固な術後癒着を しているためと考えられた。癒着剥離、右卵巣襄 腫摘出術 rt-LUNAを施行することで術後に排 便時痛は解消した。症例 3 は29歳 4 回経妊 2 回 経産の症例で 左下腹痛を主訴に来院した。双合 診および画像検査にて機質的異常を認めないもの の保存的治療が無効であったため、腹腔鏡を施行 した。骨盤内所見に異常を認めず、LUNAを施行 することにより著明な症状の改善を認めた。腹腔 鏡はchronic pelvic painの診断および治療に有効 である。

\section{腹腔鏡下に摘出した腹腔内異物の一例}

琉球大学医学部器官病態医科学講座女性 - 生殖医学 分野

\section{○照屋陽子 神山茂 野原理 金澤浩二}

腹部手術後の異物遺残は、その摘出に再度の手 術を必要とするため、患者への負担は大きく、術 者は手術時に十分な注意を払い、異物遺残のない ように努めるべきである。今回我々は、不妊症精 査中に既往手術時のガーゼ遺残を疑う所見を認め た症例に対し、腹腔鏡下に異物摘出を施行したの で報告する。

症例は 41 歳、 2 経妊 0 経産、 2 年 8 ケ月の不妊、 挙児希望を主訴に平成 14 年 3 月に当科を受診し た。平成11年 5 月から不妊症治療目的に当科に通 院し、同年7月に腹腔鏡下卵管再疎通術を受ける も、以後通院中断、平成 12 年 2 月に自然妊娠成立 するも流産（IUFD）となった。平成13年 5 月に 他医にて開腹による右卵巣チョコレート襄胞摘出 及び両側付属器癒着剥離術を受けた既往がある。 外来での子宮卵管造影検査施行時に、ワイヤーの 腹部への迷入を認め、開腹手術の既往歴、CT検 査所見よりガーゼ遺残を疑った。自覚症状は特に なし。ガーゼ摘出及び不妊症精査目的に腹腔鏡を 施行。腹腔内は大網と腹壁が癒着、Douglas窩は 閉鎖、子宮付属器の癒着は強度で、腸管との癒着 も認められた。遺残ガーゼは一見したところは不 明であったが、子宮底近くの腸管、大網を検索し たところ、硬い腫瘤が認められ、白色調の部分が 透見された。同部位を鉗子にて鈍的に穿破したと ころ内部に膿性の分泌物とガーゼが確認できた。 ガーゼは一部脆弱となっていたが、鉗子での毫引 により摘出可能であった。カプセル状になり、膿 性分泌物が貯留していた部は十分に洗浄し、手術 を終了した。術後経過は良好で、術後 5 日目に退 院となった。

今回腹腔内異物の摘出として腹腔鏡手術を施行 したが、再開腹術を施行する場合と比較して、患 者の負担の軽減をはかることができたと思われ た。遺残期間や症状、周囲組織との癒着の程度等 により手術法選択の検討が必要と思われるが、侵 襲のより軽度な腹腔鏡による異物摘出術は試みて よい方法と思われた。 


\section{当科における緊急腹腔鏡下手術の検討}

北里大学医学部産婦人科学

○西村真純 本橋恵美子 藤田一博 武井恵理子 石川雅一 川内博人

産婦人科領域における腹腔鏡下手術は近年、め ざましい医療機器の進歩と手術手技の向上により 広く普及しつつある。また、産婦人科臨床におけ る緊急手術が必要な症例においても、術後の早期 回復を期待する目的で腹腔鏡下手術が選択される ことも多い。今回、当科における緊急腹腔鏡下手 術を後方視的に検討した。1991年より2003年まで の14年間に当科で行った腹腔鏡下手術は1646例 で、このうち緊急例は261例（15.9\%）であった。 疾患別の内訳は子宮外妊娠（腹腔鏡下卵管切開内 容除去術、腹腔鏡下卵管切除術等含む）が最も多 く、261例中 212 例 $(81.2 \%)$ であった。子宮外妊 娠以外の疾患としては卵巣囊腫茎捻転 21 例 $(8.0 \%)$ 、卵管水腫茎捻転 4 例 $(1.5 \%)$ 、骨盤内感 染症 10 例 $(3.8 \%)$ 、卵巣出血 5 例 $(1.9 \%)$ 、卵巣 囊胞破裂 4 例 $(1.5 \%)$ 、虫垂炎 3 例 $(1.1 \%)$ 、筋 腫分婏 2 例 $(0.7 \%)$ であった。卵巣囊腫茎捻転 例のうち 3 例は妊娠初期であった。子宮外妊娠例 における症例の平均年齢は 29.0 歳、平均手術時間 は80.9分だった。年度別に手術件数を比較すると、 1991年から1997年までは年間14から29例であった が、1998年以降は年間14例以下となっており、 2003年は3例のみだった。1997年以降は子宮外妊 娠に対し経胵的薬物局所注入法を主に施行してい るため、1997年以降の緊急腹腔鏡下手例は減少傾 向である。また、17時以降の当直帯での緊急腹腔 鏡下手術例は261例中231例でそのほとんどが夜間 帯で手術が施行されていた。

\section{NSAID 2 剤による術後疼痛管理の効果の比較}

\author{
順天堂大学産婦人科学教室
}

○塩沢葉子、島貫洋人、杉村彩子、菊地 盤、 武内裕之、木下勝之

【目的】腹腔鏡下手術は一般的に術創が小さく術 後疼痛が少ない。効率的な術後疼痛管理を行うこ とによってさらなる患者の苦痛の軽減が可能であ ると思われる。そこで、抜管直後から疼痛管理を 行い、薬剂別にVASを用いてその効果を比較し た。【方法】2002年11月から2003年 2 月までに当 科で施行された腹腔鏡下手術103例を対象とした。 手術は全身麻酔下に行い、トロカール刺入部 4 ケ 所には $0.375 \%$ アナペイン $5 \mathrm{~m} 1$ ずつ計 $20 \mathrm{~m} 1$ の局 所麻酔を併用した。術後鎮痛剂の投与は抜管直後 に行い、投与薬剂は期間別にフルルビプロフェン アキセチル50mg使用したR群35例、ジクロフェ ナクナトリウム $50 \mathrm{mg}$ を使用したB群 28 例、投与 しなかったコントロールC群40例の 3 群に分類し た。術後疼痛の評価はVAS（visual analog scale）を用いて病室帰室時、 1 時間後、3 時間 後、 6 時間後、 9 時間後、24時間後に行った。ま た追加の鎮痛剤投与はまずジクロフェナク坐薬、 無効例にペンタゾシン $30 \mathrm{~m} \mathrm{~g}$ 筋肉注射を投与し、 その有無、薬剤の種類、追加投与までの時間を調 査した。3 群間で統計学的に比較した。

【結果】 3 群の患者年齢（才）及び手術時間（分） の平均は有意差はなかった。 3 群 $(\mathrm{R}$ 群/B群/C 群）それぞれの病室帰室時、6 時間後、24時間後 のVASの中央值は $(4 / 5 / 5) 、(3 / 2 / 2) 、(2 / 2 / 2)$ で有意差は認めなかった。また追加の鎮痛剂の投 与例はジクロフェナク座薬84例、塩酸ペンタゾシ ン筋注は47例（重複38例）で、投与回数、追加投 与までの時間に3群間で有意差は認めなかった。

【結論】術後VASについてコントロール群と有意 差がなかったことから、腹腔鏡下手術の術後疼痛 は一般的に言われているように少ないと思われ た。フルルビプロフェンアキセチルやジクロフェ ナクナトリウムの予防投与は有効な鎮痛効果は得 られなかった。 